Word count

Abstract: 250

Main text: 3287

Figures 3

Tables 3

Supplementary Materials

\title{
Accelerated Epigenetic Ageing in Major Depressive Disorder
}

\author{
${ }^{1}$ Heather C Whalley ${ }^{*},{ }^{1}$ Jude Gibson ${ }^{2,3}$ Riccardo Marioni, ${ }^{2,4}$ Rosie M Walker, \\ ${ }^{1}$ Toni-Kim Clarke, ${ }^{1}$ David M Howard, ${ }^{1}$ Mark J Adams, Lynsey Hall, ${ }^{4}$ Stewart
}

Morris, ${ }^{2,3}$ lan J Deary, ${ }^{2,4}$ David Porteous, 23andMe Research Team ${ }^{5}$, Major

Depressive Disorder Working Group of the Psychiatric Genomics Consortium

${ }^{2,4}$ Kathryn L Evans ${ }^{\#},{ }^{2,3}$ Andrew M McIntosh ${ }^{\#}$.

${ }^{1}$ Division of Psychiatry, University of Edinburgh, Edinburgh, UK.
${ }^{2}$ Centre for Cognitive Ageing and Cognitive Epidemiology, University of Edinburgh, Edinburgh, UK.

${ }^{3}$ Department of Psychology, University of Edinburgh, Edinburgh, UK

${ }^{4}$ Centre for Genetics and Experimental Medicine, IGMM, Western General Hospital, University of Edinburgh, Edinburgh, UK.

${ }^{5}$ 23andMe, Inc., Mountain View, CA, USA

\# authors contributed jointly

"Correspondence: Dr Heather C Whalley

University of Edinburgh

Royal Edinburgh Hospital

Morningside Park

Edinburgh EH10 5HF

UK

Telephone: +44 1315376502

Email: heather.whalley@ed.ac.uk 
Accelerated epigenetic ageing in depression

\section{Abstract}

Background: Major depressive disorder (MDD) is a severe, heritable psychiatric disorder associated with shortened lifespan and comorbidities of advancing age. It is unknown however whether MDD is associated with accelerated biological ageing relative to chronological age. This hypothesis was tested using the epigenetic clock as a measure of biological age.

Methods: To address the main hypothesis, using peripheral blood, we derived measures of Epigenetic Age Acceleration (EAA) in 3,833 controls and 1,219 MDD cases based on Hannum and Horvath epigenetic clocks in Generation Scotland (GS:SFHS, mean age 48 years, std dev 14.5). Models controlled for relatedness, sex, cell counts, and processing batch (basic model), as well as additional covariates of smoking and drinking status, and body mass index (BMI) (full models).

Results: Accelerated epigenetic ageing was found in MDD cases versus controls using the Horvath clock ( $\beta=0.0804, p=0.012$ equivalent to 0.20 years) in both the basic and full models. Significant MDD*age interactions indicated greatest effects at younger age ranges. No significant differences were observed for the Hannum clock. BMI was the only additional covariate found to attenuate the relationship between EAA $_{\text {Horvath }}$ and MDD. Further, genetic correlation analysis indicated significant overlap in the genetic aetiology of $\mathrm{EAA}_{\text {Horvath }}$ with $\mathrm{BMI}\left(\mathrm{r}_{\mathrm{G}}=0.20, \mathrm{p}=0.03\right)$, between $\mathrm{MDD}$ with $\mathrm{BMI}\left(\mathrm{r}_{\mathrm{G}}=0.10\right.$, $\left.\mathrm{p}=9.86 \times 10^{-6}\right)$, but not between $\mathrm{EAA}_{\text {Horvath }}$ and $\operatorname{MDD}\left(\mathrm{r}_{\mathrm{G}}=0.14, \mathrm{p}=0.125\right)$. Mediation analysis indicated partial mediation of the relationship between $\mathrm{EAA}_{\text {Horvath }}$ and depression status through $\mathrm{BMI}(\beta=0.0028 ; \mathrm{p}=0.0248, \sim 13 \%)$. 
bioRxiv preprint doi: https://doi.org/10.1101/210666; this version posted October 28,2017 . The copyright holder for this preprint (which was not certified by peer review) is the author/funder, who has granted bioRxiv a license to display the preprint in perpetuity. It is made available under aCC-BY-ND 4.0 International license.

Accelerated epigenetic ageing in depression

Conclusion: These data imply that accelerated biological ageing is associated with MDD and partially mediated through BMI. 
Accelerated epigenetic ageing in depression

\section{Introduction}

Major depressive disorder (MDD) is a heritable and disabling psychiatric condition that has recently become the leading cause of disability worldwide (1). Depression is associated with a number of age-related co-morbid physical conditions, including atherosclerosis, heart disease, hypertension and stroke (2). Further, MDD is associated with reduced life expectancy (3). Faster biological ageing in MDD has been suggested as one possible mechanism for these associations $(2,4)$.

Several lines of convergent evidence support the premise of accelerated biological ageing in MDD. Firstly, genetic evidence demonstrates a significant overlap between molecular pathways implicated in depression and normal ageing $(2,4-6)$. In some studies, particularly in the domains of memory and psychomotor speed, MDD and ageing are also both associated with reduced cognitive function as well as having overlapping structural and functional brain changes (5). Telomere shortening, a measure associated with reduced lifespan and hence proposed as an objective measure of ageing, is also found in some studies of individuals with $\operatorname{MDD}(7,8)$.

DNA methylation changes are strongly associated with the ageing process and may give rise to downstream changes in gene expression and function (9). More recently, studies addressing the dynamic nature of DNA methylation with age have identified various sites within the genome where changes preferentially occur (9). DNA methylation levels at particular sites can be used to derive a score that is highly correlated with chronological age (1012). These 'epigenetic clocks' have also been shown to predict all-cause mortality and lifespan (13-15); those with faster running clocks relative to 
chronological age have a reduced life expectancy. These peripherally-derived patterns of DNA methylation therefore provide an important instrument for the investigation of biological ageing in MDD.

We primarily sought to determine if MDD status was associated with acceleration of biological ageing. We employed two commonly used measures of DNA methylation age (DNAm age): the Hannum and Horvath clocks (10-12). We hypothesised that MDD would be associated with a higher DNAm age relative to chronological age, otherwise known as epigenetic age acceleration (EAA). We sought to test these predictions in a large populationbased cohort study, the Generation Scotland: Scottish Family Health Study sample (GH:SFHS) $(16,17)$. 
Accelerated epigenetic ageing in depression

\section{Methods and Materials}

\section{Study Participants}

\section{Generation Scotland: the Scottish Family Health Study (GS:SFHS)}

GS:SFHS is a family and population-based cohort study with participants recruited at random through general medical practices across Scotland. All participants were asked to refer at least one relative to the study, but neither recruitment nor referral of a relative was dependent on the diagnostic status of any particular condition or health outcome. Initial data collection took place between 2006 and 2011. The complete study protocol is described in detail elsewhere (16-18). Brief details of assessments relevant to the current study are summarised below. Ethical approval was provided by NHS Tayside Research Ethics Committee (05/S1401/89) and written consent for the use of data was obtained from all participants.

The full GS:SFHS cohort consisted of 23,690 individuals ( $>18$ years of age at recruitment). The present study includes 5,052 individuals on whom DNA methylation data was acquired at baseline and subsequently analysed as part of a follow-up study of GS:SFHS participants, 'Stratifying Depression And Resilience Longitudinally' (STRADL). Briefly, individuals were selected for DNA methylation profiling based on the availability of existing longitudinal data. Individuals who participated in the Aberdeen Children of the 1950 s and Walker birth cohort studies were preferentially selected (19-21), followed by those who provided further face-to-face or questionnaire-based phenotyping of depression status.

\section{Clinical assessment in GS:SFHS}


MDD was diagnosed using the structured clinical interview for the Diagnostic and Statistical Manual of Mental Disorders (SCID) (22). A brief screening questionnaire was administered in which participants were asked "Have you ever seen anybody for emotional or psychiatric problems?" and "Was there ever a time when you, or someone else, thought you should see someone because of the way you were feeling or acting?". If they answered 'yes' to either of these questions, they were asked to complete the SCID (22). If they answered 'no' to both questions, they were assigned control status. Those who completed the SCID but did not meet the criteria for MDD or other major psychiatric disorder were also defined as controls. Individuals who declined to complete the screening questionnaire or SCID were not included in further analysis. Individuals were also asked about smoking and drinking status. Individuals were asked 'Have you ever smoked tobacco?', or 'Have you ever had an alcoholic drink?'. They were requested to respond according to: (i) Yes, currently smoke/drink, (ii) Yes, but stopped within past 12 months, (iii) Yes, but stopped more than 12 months ago, (iv) No, never smoked/drank. BMI was calculated using height $(\mathrm{cm})$ and weight $(\mathrm{kg})$ measured by trained clinical staff.

\section{Derivation of the epigenetic clock}

Whole blood genomic DNA (500 ng) samples from 5,200 individuals were treated with sodium bisulphite using the EZ-96 DNA Methylation Kit (Zymo Research, Irvine, California), following the manufacturer's instructions. DNA methylation was assessed using the Infinium MethylationEPIC BeadChip (Illumina Inc., San Diego, California), in accordance with the manufacturer's 
protocol. The arrays were scanned using a HiScan scanner (Illumina Inc., San Diego, California) and initial inspection of array quality was carried out using Genome Studio v2011.1.

Additional quality control measures were implemented using the $\mathrm{R}$ packages 'shinyMethyl' $(23,24)$ and 'wateRmelon' (23). First, shinyMethyl was used to plot the log median intensity of the methylated signal against the log median intensity of the unmethylated signal for each array. Outliers from this QC plot were visually identified and excluded from further analysis. Methylation beta-values were then entered into the 'pfilter' function in wateRmelon which was used to exclude poor-performing samples and probes. Samples were excluded if $\geq 1 \%$ sites had a detection $p$-value of $>$ 0.05. Probes were removed from the dataset if: (i) they had more than 5 samples with a beadcount of less than 3 ; or (ii) $\geq 0.5 \%$ samples had a detection $p$-value of $>0.05$. Finally, shinyMethyl's sex prediction plot was used to exclude samples whose predicted sex differed from their recorded sex. After QC, the dataset comprised beta-values for 860,926 methylation loci measured in 5,101 individuals.

The DNAm age measures were calculated using the coefficients reported in the Hannum and Horvath publications (10-12). Of the 71 CpGs in the Hannum clock, 65 were included in the QCd current dataset and 335 of the 353 Horvath clock CpGs. Correlations between the clocks with chronological age in a sub-sample of 2,586 individuals (selected to be unrelated and not share a nuclear environment; no couples and no pairs with pi-hat>0.05) are shown in Supplementary Figure 1, $r=0.94$ and $r=0.91$ for Hannum and Horvath clocks respectively. As an additional QC measure, we 
performed analysis excluding data where epigenetic age values fell out-with three standard deviations from the group mean. The current sample of individuals with QC'd epigenetic data and MDD status data therefore included $\mathrm{n}_{\text {Hannum }}=3,830$ controls, $\mathrm{n}_{\text {Hannum }}=1,217$ MDD cases and $\mathrm{n}_{\text {Horvath }}=3,833$ controls, $\mathrm{n}_{\text {Horvath }}=1,219$ MDD cases.

Measures of 'epigenetic age acceleration' (EAA) were derived from both the Horvath and Hannum clocks, by regressing DNAm age on chronological age and taking the corresponding residuals as the EAA measure. A positive EAA value indicates that DNAm age is higher than chronological age (accelerated ageing), and negative EAA values represent younger biological age compared to chronological age.

\section{Statistical modelling}

All analyses were conducted in ASReml-R (www.vsni.co.uk/software/asreml, version 3.0). Associations were examined between EAA as the dependent variable and MDD status as the independent variable, controlling for sex using mixed linear model association analysis. Since GS:SFHS is a family-based study, family structure was fitted as a random effect by creating an inverse relationship matrix using pedigree kinship information to control for relatedness (25). These covariates (sex, relatedness), as well as measures of blood cell-type composition (including CD8T, CD4T, NK, B cells and granulocytes, estimated using minfi's 'estimateCellCounts' function) and processing batch, were included in the basic model $(13,14)$.

Further covariates were also added to test sensitivity of the regression model to potential confounding lifestyle and health-related factors previously 
associated with DNAm (full models). These included self-reported smoking and alcohol intake/consumption (as described above). In addition, since there is a known relationship between obesity and accelerated epigenetic ageing (26), and between obesity and MDD (27), we also explored the contribution of body mass index (BMI, as a proxy for obesity) to the relationship between EAA and depression status.

Additional models to account for potential interaction effects of covariates (age and sex) on MDD status (e.g. modelling MDD*age, MDD*sex) are contained within supplementary materials (Supplementary Tables 1a.b).

Out of the three additional covariates (smoking, drinking status and $\mathrm{BMI}), \mathrm{BMI}$ was the only one that demonstrated an attenuating effect on the relationship between EAA and MDD status. We therefore further examined the shared genetic aetiology between EAA, MDD and BMI. To test the potential overlap in polygenic architecture between EAA, MDD and BMI, and estimate the size and significance of any genetic correlation, we used cross-trait Linkage Disequilibrium Score regression (LD Score regression) $(28,29)$. We followed the protocol outlined by Bulik-Sullivan et al. (29), using data from GWAS analyses of EAA Hannum $(n=5047)$ and EAA Horvath $(n=5052)$ from the current sample (see supplemental materials), summary statistics from the recent GWAS of BMI from the GIANT consortium (30), and summary statistics from the largest available GWAS of MDD ( $N=453,779$, of which 129,667 were MDD cases), carried out by the Psychiatric Genomics Consortium (31), which includes summary statistics from the personal genetics company 23andMe, Inc., (32) and UK Biobank (with Generation Scotland samples removed). 
We additionally conducted a formal mediation analysis of the relationship between EAA and MDD, as mediated through BMI, using the 'testMediation' function in R using the Sobel method on an unrelated sample of individuals (controls $n=1,301$, MDD cases $n=463$ ). In each case EAA was entered as the independent variable, MDD status was entered as the dependent variable, and BMI was entered as the mediating variable. Covariates included were sex, cell counts and batch, along with smoking and drinking status. For completeness, we also tested for mediation effects of smoking and drinking status on the relationship between EAA and depression status, see supplementary materials.

For all analyses, all continuous measures were rescaled into zero mean and unitary standard deviation in order that effect sizes represent standardized scores. 
Accelerated epigenetic ageing in depression

\section{Results}

\section{Demographics}

Sample characteristics are presented in Table 1. There was no significant difference in chronological age between cases and controls $(t=-0.2131$, $\mathrm{p}=0.83)$. Individuals with MDD were more likely to be female $\left(\chi^{2}=74.864, p<\right.$ $\left.2.2 \times 10^{-16}\right)$, more likely to be current smokers $\left(\chi^{2}=30.251, p=1.2 \times 10^{-6}\right)$, and less likely to be current drinkers $\left(\chi^{2}=56.645, p=3.06 \times 10^{-12}\right)$ than control individuals (see Table 1). Body mass index (BMI) was greater in MDD cases than controls (controlling for sex, $\beta=0.1106, p=8.38 \times 10^{-4}$ ), see Table 1 .

\section{MDD Status and Epigenetic Age Acceleration (EAA): Basic Models}

Epigenetic age and epigenetic age acceleration measures are presented in Table 1 for both clock-based methods for MDD cases and controls. No group differences were found for $\mathrm{EAA}_{\text {Hannum }}$ in any of the models (Table 2). The EAA $_{\text {Horvath }}$ however indicated significantly increased epigenetic age acceleration in depressed cases versus controls, see Figure 1, Table 2, with an overall mean positive value in cases (accelerated ageing, equivalent to 0.20 years) and a mean negative value (decelerated ageing, equivalent to 0.07 years) in controls. For the $\mathrm{EAA}_{\text {Horvath }}$ analysis controlling for relatedness and sex, the effect size was $\beta=0.1103, p<0.001$. In the analysis controlling for relatedness, sex, as well as processing batch and cell counts, the effect size was $\beta=0.0804, p=0.012$.

Figure 2 demonstrates a scatterplot of EAA $_{\text {Horvath }}$ versus chronological age coded by MDD status, which indicated a greater difference in $\mathrm{EAA}_{\text {Horvath }}$ in MDD individuals versus controls at the younger age range of the cohort. 
Accelerated epigenetic ageing in depression

\section{MDD Status and Epigenetic Age Acceleration (EAA): Full Models}

To determine whether observed increases in EAA Horvath in MDD were due to potential confounding lifestyle and health-related factors, the previous statistical models were run including smoking status as an additional covariate. Here MDD status remained significantly associated with increased EAA $_{\text {Horvath }}(\beta=0.0811, p=0.013)$. The next sensitivity analysis included all above covariates plus smoking and drinking status, and again MDD status remained significantly associated with increased $E A A_{\text {Horvath }}(\beta=0.0765$, $\mathrm{p}=0.020$ ). With the incremental inclusion of $\mathrm{BMI}$ in the model the results were also still significant $(\beta=0.0647, p=0.049)$.

Table 2 also demonstrates the effect of these additional covariates added separately to the model. Only smoking $(\beta=-0.0256, p=0.039)$ and BMI $\left(\beta=0.0886, p=2.22 \times 10^{-10}\right)$ demonstrated a significant effect in these models. However, only BMI demonstrated an attenuation of the effect size in relation to MDD status (from $\beta=0.0804$ to $\beta=0.0690$ with the addition of $B M I, \beta=0.0804$ to $\beta=0.0811$ with the addition of smoking, and $\beta=0.0804$ to $\beta=0.0834$ with the addition of drinking status).

\section{MDD * age/sex interaction effects}

The inclusion of the age ${ }^{\star} \mathrm{MDD}$ and sex*MDD interaction terms as covariates are presented in Supplementary Table 1a. The addition of these covariates either singly or together in the same model did not alter the main pattern of results described above for effects of MDD status (increased EAA in MDD cases), with the exception of the full models incrementally including all 
covariates plus BMI where results fell to just below significant $(\beta=0.0644$, $\mathrm{p}=0.051)$. Notably, the MDD*age interaction term was itself significant in these full models ( $\beta=-0.0723$ to $\beta=-0.0952, p<=0.05$ ), as reflected in the divergence of the groups at the younger age range of the cohort, depicted in Figure 2. MDD*sex interactions were not significant.

\section{Genetic correlation analysis: EAA, MDD and BMI}

Genetic correlation analysis indicated there was a significant shared genetic architecture between $\mathrm{EAA}_{\text {Horvath }}$ and $\mathrm{BMI}\left(\mathrm{r}_{\mathrm{G}}=0.20, \mathrm{p}=0.031\right)$, and between MDD and BMI ( $r_{G}=0.10, p=9.86 \times 10^{-6}$, see Table 3, Figure 3), but not between $\mathrm{EAA}_{\text {Horvath }}$ and MDD $\left(r_{\mathrm{G}}=0.14, \mathrm{p}=0.125\right)$. The genetic correlation between $\mathrm{EAA}_{\text {Hannum }}$ and $\mathrm{EAA}_{\text {Horvath }}$ also indicated shared architecture between the two measures of accelerated ageing $\left(r_{G}=0.68, p=0.035\right)$, though there were no significant genetic correlations between $\mathrm{EAA}_{\text {Hannum }}$ and MDD or BMI.

\section{Mediation analysis: EAA, MDD and BMI}

Tests of formal mediation suggested that BMI partially mediated the relationship between EAA and depression status. Specifically, the Sobel test showed a significant mediating effect of BMI between $\mathrm{EAA}_{\text {Horvath }}$ and depression status $(\beta=0.0028, p=0.025$, see Figure 3 and Supplementary Table 2). The proportion of the effect mediated by BMI (indirect effect/total effect) was $12.79 \%$. Mediating effects of smoking and drinking did not significantly mediate this relationship $(\beta=0.0006, p=0.291,4.11 \%, \beta=<0.0001, p=0.251$, $<0.01 \%$ respectively). 
Accelerated epigenetic ageing in depression

\section{Discussion}

To our knowledge this is the largest study to date ( $>5,000$ individuals) of epigenetic ageing in depressed cases versus controls. As hypothesised, we demonstrate that MDD is associated with a significantly higher EAA Horvath, contributing to the increasing body of evidence indicating accelerated biological ageing as a core feature of the disorder. The analysis further indicated that the observed epigenetic age acceleration effects in MDD were not due to confounding effects related to processing batch or cell counts, and were not attributable to smoking or drinking status. This difference between cases and controls was small (equating to 0.20 years), which may in part relate to the extensive heterogeneity associated with MDD (33). In contrast to our expectation that differences between MDD cases and controls would increase with age, we found larger differences in EAA towards the younger end of the cohort's age range (see Figure 2).

Numerous lines of evidence have previously led to suggestions of accelerated ageing effects in MDD. These include observations that depressed individuals demonstrate an increased risk of ageing-related diseases and reduced life expectancy (3), overlapping biological pathways involved in both MDD and biological ageing (5), and evidence of excessive cellular ageing $(2,4,34)$. Ageing and ageing-related diseases are also notably associated with changes in DNA methylation, leading to the development of DNA methylation-based predictors of biological ageing (10-12). It was previously unknown however, whether accelerated ageing effects at the level of methylation using such predictors would be seen in MDD, and how these may be mediated by other factors, for example BMI. There are known robust 
reciprocal links between obesity and depression (26), and the role of increased BMI and shortened lifespan has also been extensively studied (35). More recently, studies have also reported that increases in BMI are associated with accelerated epigenetic ageing, although mechanisms are currently unknown, as are the links with comorbid diseases such as MDD (26).

The current results support the idea that there is increased epigenetic age acceleration in depressed cases versus controls. We found evidence that these relationships were partially mediated by higher BMI ( 13\%), but not with smoking or drinking status. Future research probing the potential contributions of environmental and lifestyle influences on psychological well-being in the general population could highlight the importance of risk-related and protective factors of wide applicability.

Notably our findings between the two different DNAm age predictors differed in their sensitivity with regards the categorical depression diagnosis. It is notable however that there are differences between these two DNAm age methods that may contribute to these inconsistencies. The Hannum predictor is derived from whole blood DNA from a single cohort of individuals using 71 CpGs. The Horvath model was however derived from multiple tissue types using data from multiple independent studies and uses $353 \mathrm{CpGs}$. Further, each method involves almost entirely non-overlapping CpG sites. Although both methods perform similarly in their prediction of mortality $(14,36)$, previous studies have also reported differences in their associations between other traits of interest, for example exposure to environmental particulate matter (37), with neural integrity in post-traumatic stress disorder (36), and 
with longevity (38). These studies, together with the current findings, therefore suggest that the two DNAm age biomarkers of biological ageing may reflect subtly different aspects of the ageing process.

The major strength of our study is the large sample size, with DNA methylation data available on more than 5,000 individuals, plus the availability of detailed phenotyping in our cohort. As sample sizes for GWAS of EAA increase, future work could include genetic analyses to inform causation models, such as Mendelian Randomisation. The lack of access to brain tissue is a frequently cited limitation of blood-based DNA methylation studies. Whilst we are unable to make strong inferences specifically about effects on the brain, other studies have indicated its suitability as a relevant for biomarker for such research purposes $(11,39)$. Secondly, this study is cross-sectional in nature therefore it is not possible to infer causal directionality between factors. Lastly, although we corrected for several confounders that might influence DNA methylation, such as sex, age*MDD, sex*MDD, smoking, drinking, and BMI, we cannot exclude the possibility that other factors not captured by our methods may have confounded the observed relationships.

In conclusion, our results indicate a significant increase in epigenetic age acceleration in depressed cases versus controls lending further support to the hypothesis of accelerated biological ageing in MDD. Since this effect was greatest for the younger individuals it is possible that this may also represent altered maturation. Our findings extend previous findings to suggest that the positive relationship between accelerated methylation age and depression may be partially mediated through increased BMI. Future research would be needed to determine the direction of causality, and whether these 
bioRxiv preprint doi: $h$ ttps://doi.org/10.1101/210666; this version posted October 28,2017 . The copyright holder for this preprint (which was not certified by peer review) is the author/funder, who has granted bioRxiv a license to display the preprint in perpetuity. It is made available under aCC-BY-ND 4.0 International license.

Accelerated epigenetic ageing in depression

associations can be reversed or mitigated by treatment or lifestyle interventions. 


\section{Acknowledgements}

This study is supported by a Wellcome Trust Strategic Award "Stratifying Resilience and Depression Longitudinally" (STRADL) (Reference 104036/Z/14/Z) and by the Sackler Foundation. Generation Scotland received core support from the Chief Scientist Office of the Scottish Government Health Directorates [CZD/16/6] and the Scottish Funding Council [HR03006]. Genotyping of the GS:SFHS samples was carried out by the Genetics Core Laboratory at the Wellcome Trust Clinical Research Facility, Edinburgh, Scotland and was funded by the Medical Research Council UK and the Wellcome Trust (Wellcome Trust Strategic Award (STRADL; Reference as above). HCW is supported by a JMAS SIM fellowship from the Royal College of Physicians of Edinburgh and by an ESAT College Fellowship from the University of Edinburgh. SRC is supported by a Medical Research Council (MRC) grant (MR/M013111/1). Part of the work was undertaken in The University of Edinburgh Centre for Cognitive Ageing and Cognitive Epidemiology (CCACE), part of the cross council Lifelong Health and Wellbeing Initiative (MR/K026992/1); funding from the Biotechnology and Biological Sciences Research Council (BBSRC) and MRC is gratefully acknowledged. Age UK (The Disconnected Mind project) also provided support for the work undertaken at CCACE. We would also like to thank the research participants and employees of 23andMe for making this work possible. We thank the following members of the 23andMe Research Team: Michelle Agee, Babak Alipanahi, Adam Auton, Robert K. Bell, Katarzyna Bryc, Sarah L. Elson, Pierre Fontanillas, Nicholas A. Furlotte, David A. Hinds, Karen E. Huber, Aaron Kleinman, Nadia K. Litterman, Jennifer C. McCreight, Matthew H. Mclntyre, Joanna L. Mountain, Elizabeth S. Noblin, Carrie A.M. Northover, Steven J. Pitts, J. Fah Sathirapongsasuti, Olga V. Sazonova, Janie F. Shelton, Suyash Shringarpure, Chao Tian, Joyce Y. Tung, Vladimir Vacic, and Catherine H. Wilson. 
bioRxiv preprint doi: https://doi.org/10.1101/210666; this version posted October 28, 2017. The copyright holder for this preprint (which was not certified by peer review) is the author/funder, who has granted bioRxiv a license to display the preprint in perpetuity. It is made available under aCC-BY-ND 4.0 International license.

Accelerated epigenetic ageing in depression

\section{Financial Disclosures}

AMM has previously received grant support from Pfizer, Lilly and Janssen. These studies are not connected to the current investigation. Remaining authors report no conflicts of interest. 


\section{References}

1. Organisation WH (n.d.): Depression: Lets Talk. http://www.who.int/mediacentre/news/releases/2017/world-health-day/en/. .

2. Wolkowitz OM, Reus VI, Mellon SH (2011): Of sound mind and body: Depression, disease, and accelerated aging. Dialogues Clin Neurosci. 13: 25-40.

3. Chesney E, Goodwin GM, Fazel S (2014): Risks of all-cause and suicide mortality in mental disorders: A meta-review. World Psychiatry. 13: 153-160.

4. Wolkowitz OW, Epel ES, Reus VI, Mellon SH (2010): Depression gets old fast: Do stress and depression accelerate cell aging? Depress Anxiety. 27.

5. Sibille $E$ (2013): Molecular aging of the brain, neuroplasticity, and vulnerability to depression and other brain-related disorders. Dialogues Clin Neurosci. 15: 53-65.

6. Douillard-Guilloux G, Guilloux JP, Lewis DA, Sibille E (2013): Anticipated brain molecular aging in major depression. Am J Geriatr Psychiatry. 21: 450-460.

7. Darrow SM, Verhoeven JE, Révész D, Lindqvist D, Penninx BWJH, Delucchi KL, et al. (2016): The Association Between Psychiatric Disorders and Telomere Length: A MetaAnalysis Involving 14,827 Persons. Psychosom Med. 78: 776-87.

8. Lin PY, Huang YC, Hung CF (2016): Shortened telomere length in patients with depression: A meta-analytic study. J Psychiatr Res. 76: 84-93.

9. Jones MJ, Goodman SJ, Kobor MS (2015): DNA methylation and healthy human aging. Aging Cell. 14.

10. Horvath S (2013): DNA methylation age of human tissues and cell types. Genome Biol. 14: R115.

11. Horvath S, Zhang Y, Langfelder P, Kahn RS, Boks MP, van Eijk K, et al. (2012): Aging effects on DNA methylation modules in human brain and blood tissue. Genome Biol. 13: R97.

12. Hannum G, Guinney J, Zhao L, Zhang L, Hughes G, Sadda SV, et al. (2013): Genomewide Methylation Profiles Reveal Quantitative Views of Human Aging Rates. Mol Cell. 49: 359-367.

13. Marioni RE, Shah S, McRae AF, Chen BH, Colicino E, Harris SE, et al. (2015): DNA methylation age of blood predicts all-cause mortality in later life. Genome Biol. 16: 25.

14. Chen BH, Marioni RE, Colicino E, Peters MJ, Ward-Caviness CK, Tsai PC, et al. (2016): DNA methylation-based measures of biological age: Meta-analysis predicting time to death. Aging (Albany NY). 8: 1844-1865.

15. Perna L, Zhang Y, Mons U, Holleczek B, Saum K-U, Brenner H (2016): Epigenetic age acceleration predicts cancer, cardiovascular, and all-cause mortality in a German case cohort. Clin Epigenetics. 8: 64.

16. Smith BH, Campbell A, Linksted P, Fitzpatrick B, Jackson C, Kerr SM, et al. (2013): Cohort Profile: Generation Scotland: Scottish Family Health Study (GS:SFHS). The study, its participants and their potential for genetic research on health and illness. Int $J$ Epidemiol. 42: 689-700.

17. Smith BH, Campbell H, Blackwood D, Connell J, Connor M, Deary IJ, et al. (2006): Generation Scotland: the Scottish Family Health Study; a new resource for researching genes and heritability. BMC Med Genet. 7: 74.

18. Kerr SM, Campbell A, Murphy L, Hayward C, Jackson C, Wain L V, et al. (2013): Pedigree and genotyping quality analyses of over 10,000 DNA samples from the Generation Scotland: Scottish Family Health Study. BMC Med Genet. 14: 38.

19. Batty GD, Morton SMB, Campbell D, Clark H, Smith GD, Hall M, et al. (2004): The Aberdeen Children of the 1950s cohort study: Background, methods and follow-up information on a new resource for the study of life course and intergenerational 

aCC-BY-ND 4.0 International license.

\section{Accelerated epigenetic ageing in depression}

influences on health. Paediatr Perinat Epidemiol. 18: 221-239.

20. Leon DA, Lawlor DA, Clark H, Macintyre S (2006): Cohort profile: The Aberdeen children of the 1950s study. Int J Epidemiol. 35: 549-552.

21. Libby G, Smith A, McEwan NF, Chien PFW, Greene SA, Forsyth JS, et al. (2004): The Walker Project: A longitudinal study of 48000 children born 1952-1966 (aged 36-50 years in 2002) and their families. Paediatr Perinat Epidemiol. 18: 302-312.

22. First MB et, Spitzer RL, Gibbon M, Williams JBW (2002): Structured Clinical Interview for DSM-IV-TR Axis I Disorders, Research Version, Non-patient Edition. for DSMIV. .

23. Pidsley R, Y Wong CC, Volta M, Lunnon K, Mill J, Schalkwyk LC (2013): A data-driven approach to preprocessing Illumina 450K methylation array data. BMC Genomics. 14: 293.

24. Fortin J-P, Fertig E, Hansen K (2014): shinyMethyl: interactive quality control of Illumina 450k DNA methylation arrays in R. F1000Research. . doi: 10.12688/f1000research.4680.2.

25. Whalley HC, Adams MJ, Hall LS, Clarke T-K, Fernandez-Pujals AM, Gibson J, et al. (2016): Dissection of major depressive disorder using polygenic risk scores for schizophrenia in two independent cohorts. Transl Psychiatry. 6. doi: 10.1038/tp.2016.207.

26. Nevalainen T, Kananen L, Marttila S, Jylhävä J, Mononen N, Kähönen M, et al. (2017): Obesity accelerates epigenetic aging in middle-aged but not in elderly individuals. Clin Epigenetics. 9: 20.

27. de Wit L, Luppino F, van Straten A, Penninx B, Zitman F, Cuijpers P (2010): Depression and obesity: A meta-analysis of community-based studies. Psychiatry Res. 178: 230235.

28. Bulik-Sullivan B, Finucane HK, Anttila V, Gusev A, Day FR, Loh P-R, et al. (2015): An atlas of genetic correlations across human diseases and traits. Nat Genet. 47: 12361241.

29. Bulik-Sullivan BK, Loh P-R, Finucane HK, Ripke S, Yang J, Patterson N, et al. (2015): LD Score regression distinguishes confounding from polygenicity in genome-wide association studies. Nat Genet. 47: 291-295.

30. Locke A, Kahali B, Berndt S, Justice A, Pers T (2015): Genetic studies of body mass index yield new insights for obesity biology. Nature. 518: 197-206.

31. Wray NR, Sullivan PF (2017): Genome-wide association analyses identify 44 risk variants and refine the genetic architecture of major depression. bioRxiv. . doi: https://doi.org/10.1101/167577.

32. Hyde CL, Nagle MW, Tian C, Chen X, Paciga SA, Wendland JR, et al. (2016): Identification of 15 genetic loci associated with risk of major depression in individuals of European descent. Nat Genet. 48: 1031-1036.

33. Milaneschi Y, Lamers F, Peyrot WJ, Abdellaoui A, Willemsen G, Hottenga J-J, et al. (2015): Polygenic dissection of major depression clinical heterogeneity. Mol Psychiatry. 21: 516-22.

34. Verhoeven JE, Révész D, Epel ES, Lin J, Wolkowitz OM, Penninx BWJH (2014): Major depressive disorder and accelerated cellular aging: results from a large psychiatric cohort study. Mol Psychiatry. 19: 895-901.

35. MacMahon S, Baigent C, Duffy S, Rodgers A, Tominaga S, Chambless L, et al. (2009): Body-mass index and cause-specific mortality in 900000 adults: Collaborative analyses of 57 prospective studies. Lancet. 373: 1083-1096.

36. Wolf EJ, Logue MW, Hayes JP, Sadeh N, Schichman SA, Stone A, et al. (2016): Accelerated DNA methylation age: Associations with PTSD and neural integrity. Psychoneuroendocrinology. 63: 155-162.

37. Nwanaji-Enwerem JC, Dai L, Colicino E, Oulhote Y, Di Q, Kloog I, et al. (2017): 
bioRxiv preprint doi: https://doi.org/10.1101/210666; this version posted October 28,2017 . The copyright holder for this preprint (which was not certified by peer review) is the author/funder, who has granted bioRxiv a license to display the preprint in perpetuity. It is made available under aCC-BY-ND 4.0 International license.

\section{Accelerated epigenetic ageing in depression}

Associations between long-term exposure to PM2.5 component species and blood DNA methylation age in the elderlyThe VA normative aging study. Environ Int. 102: 57-65.

38. Armstrong NJ, Mather KA, Thalamuthu A, Wright MJ, Trollor JN, Ames D, et al. (2017): Aging, exceptional longevity and comparisons of the Hannum and Horvath epigenetic clocks. Epigenomics. epi-2016-0179.

39. Tylee DS, Kawaguchi DM, Glatt SJ (2013): On the outside, looking in: A review and evaluation of the comparability of blood and brain "-omes." Am J Med Genet Part B Neuropsychiatr Genet. 162: 595-603. 
bioRxiv preprint doi: https://doi.org/10.1101/210666; this version posted October 28,2017 . The copyright holder for this preprint (which was not certified by peer review) is the author/funder, who has granted bioRxiv a license to display the preprint in perpetuity. It is made available under aCC-BY-ND 4.0 International license.

Accelerated epigenetic ageing in depression

Table 1: Sample Characteristics

\begin{tabular}{|c|c|c|c|c|c|}
\hline & \multicolumn{2}{|c|}{ Controls $(\mathrm{N}=3,833)$} & \multicolumn{2}{|c|}{ MDD cases $(\mathrm{N}=1,219)$} & \multirow[b]{2}{*}{$\begin{array}{c}\beta / X^{2} / t \\
\text { ( } p \text { value) }\end{array}$} \\
\hline & Mean & Std Dev & Mean & $\begin{array}{l}\text { Std } \\
\text { Dev }\end{array}$ & \\
\hline \multicolumn{6}{|c|}{ Demographic variables and Epigenetic Age } \\
\hline Age & 48.10 & 14.50 & 48.02 & 12.08 & $0.2131(0.83)$ \\
\hline Gender* (F:M), \%F & $2228: 1605$ & $58 \%$ & $878: 341$ & $72 \%$ & $\begin{array}{c}74.86 \\
\left(2.2 \times 10^{-16}\right)\end{array}$ \\
\hline Hannum age & 45.53 & 10.5 & 45.46 & 8.70 & See table 2 \\
\hline Hannum age accel & 0.0006 & 3.17 & -0.0019 & 2.97 & See table 2 \\
\hline Horvath age* & 52.49 & 9.83 & 52.70 & 8.23 & See table 2 \\
\hline Horvath age accel* & -0.0652 & 3.53 & 0.2050 & 3.40 & See table 2 \\
\hline \multicolumn{6}{|c|}{ Symptoms, lifestyle and health-related variables } \\
\hline Smoking status\%*\# & $17.7 ; 3.2 ; 25.6 ; 53.5$ & - & $22.8 ; 3.2 ; 29.3 ; 44.7$ & - & $\begin{array}{c}30.251 \\
\left(1.20 \times 10^{-6}\right)\end{array}$ \\
\hline Drinking status\%*\# & $91.5 ; 1.6 ; 4.0 ; 2.9$ & - & $86.1 ; 2.2 ; 9.5 ; 2.2$ & - & $\begin{array}{c}56.645 \\
\left(3.06 \times 10^{-12}\right)\end{array}$ \\
\hline BMI* & 26.88 & 5.16 & 27.52 & 5.96 & $\begin{array}{c}0.1106 \\
\left(8.38 \times 10^{-4}\right)\end{array}$ \\
\hline
\end{tabular}

*Significantly different $(p<0.05)$ between groups, see text.

\# See methods $1=y$ es to $4=$ no, presented as $\%$ per category 
Table 2 Epigenetic Age Acceleration in MDD Cases versus Controls

\begin{tabular}{|c|c|c|c|c|}
\hline \multirow[b]{2}{*}{ EAA Horvath clock (basic model): } & \multicolumn{4}{|c|}{ MDD effects } \\
\hline & \multicolumn{2}{|c|}{$\beta$} & \multicolumn{2}{|l|}{$P$ value } \\
\hline Controlling for relatedness, sex & \multicolumn{2}{|c|}{0.1103} & \multicolumn{2}{|c|}{$8.41 \times 10^{-4}$} \\
\hline Controlling for above plus cell counts and batch & \multicolumn{2}{|c|}{0.0804} & \multicolumn{2}{|c|}{0.012} \\
\hline \multicolumn{5}{|l|}{$\begin{array}{l}\text { EAA Horvath clock (full model): } \\
\text { incremental inclusion of covariates }\end{array}$} \\
\hline Controlling for above plus smoking & \multicolumn{2}{|c|}{0.0811} & \multicolumn{2}{|c|}{0.013} \\
\hline Controlling for above plus drinking & \multicolumn{2}{|c|}{0.0765} & \multicolumn{2}{|c|}{0.020} \\
\hline Controlling for above plus BMI & \multicolumn{2}{|c|}{0.0647} & \multicolumn{2}{|c|}{0.049} \\
\hline \multirow[b]{2}{*}{$\begin{array}{l}\text { EAA Horvath clock (full model: separate inclusion of } \\
\text { covariates) }\end{array}$} & \multicolumn{2}{|c|}{ MDD effects } & \multicolumn{2}{|c|}{ Covariate effects } \\
\hline & $\beta$ & $P$ value & $\beta$ & $P$ value \\
\hline Controlling for relatedness, sex, cell counts and batch & 0.0804 & 0.012 & - & - \\
\hline $\begin{array}{l}\text { Controlling for relatedness, sex, cell counts, batch: \& } \\
\text { smoking only }\end{array}$ & 0.0811 & 0.013 & -0.0250 & 0.038 \\
\hline $\begin{array}{l}\text { Controlling for relatedness, sex, cell counts, batch: } \\
\text { drinking only }\end{array}$ & 0.0834 & 0.011 & -0.0008 & 0.967 \\
\hline $\begin{array}{l}\text { Controlling for relatedness, sex, cell counts, batch: \& } \\
\text { BMI only }\end{array}$ & 0.0690 & 0.031 & -0.0900 & $7.35 \times 10^{-11}$ \\
\hline
\end{tabular}

\begin{tabular}{|l|c|c|}
\hline EAA Hannum clock (basic model): & $\boldsymbol{\beta}$ & MDD effects \\
\hline Controlling for relatedness, sex & 0.0456 & 0.165 \\
Controlling for above plus cell counts and batch & 0.0430 & 0.158 \\
\hline EAA Hannum clock (full model): & & 0.255 \\
incremental inclusion of covariates & 0.0351 & 0
\end{tabular}




\begin{tabular}{|c|c|c|c|c|}
\hline \multirow{4}{*}{$\begin{array}{l}\text { Controlling for above plus drinking } \\
\text { Controlling for above plus BMI }\end{array}$} & \multicolumn{2}{|c|}{0.0308} & \multicolumn{2}{|c|}{0.322} \\
\hline & \multicolumn{2}{|c|}{0.0208} & \multicolumn{2}{|c|}{0.503} \\
\hline & \multicolumn{2}{|c|}{ MDD effects } & \multicolumn{2}{|c|}{ Covariate effects } \\
\hline & $\beta$ & $P$ value & $\beta$ & $P$ value \\
\hline Controlling for relatedness, sex, cell counts and batch & 0.0430 & 0.158 & - & - \\
\hline $\begin{array}{l}\text { Controlling for relatedness, sex, cell counts, batch: \& } \\
\text { smoking only }\end{array}$ & 0.0351 & 0.255 & -0.0759 & $6.96 \times 10^{-11}$ \\
\hline $\begin{array}{l}\text { Controlling for relatedness, sex, cell counts, batch: } \\
\text { drinking only }\end{array}$ & 0.0454 & 0.143 & -0.0295 & 0.131 \\
\hline $\begin{array}{l}\text { Controlling for relatedness, sex, cell counts, batch: \& } \\
\text { BMI only }\end{array}$ & 0.0350 & 0.251 & -0.0763 & $6.24 \times 10^{-9}$ \\
\hline
\end{tabular}


bioRxiv preprint doi: https://doi.org/10.1101/210666; this version posted October 28,2017 . The copyright holder for this preprint (which was not certified by peer review) is the author/funder, who has granted bioRxiv a license to display the preprint in perpetuity. It is made available under aCC-BY-ND 4.0 International license.

\section{Accelerated epigenetic ageing in depression}

Table 3 Results of cross-trait LD Score regression analysis

\begin{tabular}{|c|c|c|c|c|c|}
\hline Trait 1 & Trait 2 & Trait 1 heritability & Trait 2 heritability & Genetic correlation & P-value \\
\hline $\mathrm{EAA}_{\text {Horvath }}$ & MDD & $0.2098(0.1002)$ & $0.0881(0.0039)$ & $0.1387(0.0913)$ & 0.125 \\
\hline EAA $_{\text {Horvath }}$ & BMI & $0.2104(0.1075)$ & 0.1391 (0.0079) & $0.1962(0.0907)$ & 0.031 \\
\hline MDD & BMI & $0.0892(0.0036)$ & $0.1391(0.0082)$ & $0.1007(0.0228)$ & $9.86 \times 10^{-6}$ \\
\hline $\mathrm{EAA}_{\text {Horvath }}$ & $\mathrm{EAA}_{\text {Hannum }}$ & $0.1779(0.0928)$ & $0.1147(0.0889)$ & $0.6807(0.3234)$ & 0.035 \\
\hline $\mathrm{EAA}_{\text {Hannum }}$ & MDD & $0.0972(0.0862)$ & $0.0881(0.0039)$ & $0.1381(0.1603)$ & 0.326 \\
\hline $\mathrm{EAA}_{\text {Hannum }}$ & BMI & $0.0886(0.0846)$ & $0.1390(0.0079)$ & $0.2287(0.1568)$ & 0.145 \\
\hline
\end{tabular}

Note: MDD data from PGC BMI data from GIANT, see methods for further details. Heritabilities reported are on the observed scale for continuous traits (age acceleration and BMI) and on the liability scale for MDD. Significant $p$-values $(p<0.05)$ are highlighted in bold. 
bioRxiv preprint doi: https://doi.org/10.1101/210666; this version posted October 28,2017 . The copyright holder for this preprint (which was not certified by peer review) is the author/funder, who has granted bioRxiv a license to display the preprint in perpetuity. It is made available under aCC-BY-ND 4.0 International license.

Accelerated epigenetic ageing in depression

Figure 1: Boxplots of EAA (Horvath) according to MDD status.

Boxplot of Epigenetic Age Acceleration according to the Horvath clock according to case-control status with mean and $95 \% \mathrm{Cls}$ 
bioRxiv preprint doi: https://doi.org/10.1101/210666; this version posted October 28,2017 . The copyright holder for this preprint (which was not certified by peer review) is the author/funder, who has granted bioRxiv a license to display the preprint in perpetuity. It is made available under aCC-BY-ND 4.0 International license.

Accelerated epigenetic ageing in depression

Figure 2: Scatterplots of EAA (Horvath) by chronological age, coded by depression status. 
bioRxiv preprint doi: https://doi.org/10.1101/210666; this version posted October 28,2017 . The copyright holder for this preprint (which was not certified by peer review) is the author/funder, who has granted bioRxiv a license to display the preprint in perpetuity. It is made available under aCC-BY-ND 4.0 International license.

Accelerated epigenetic ageing in depression

Figure 3: Mediation model and genetic correlation summary between EAA (Horvath), BMI and MDD. 


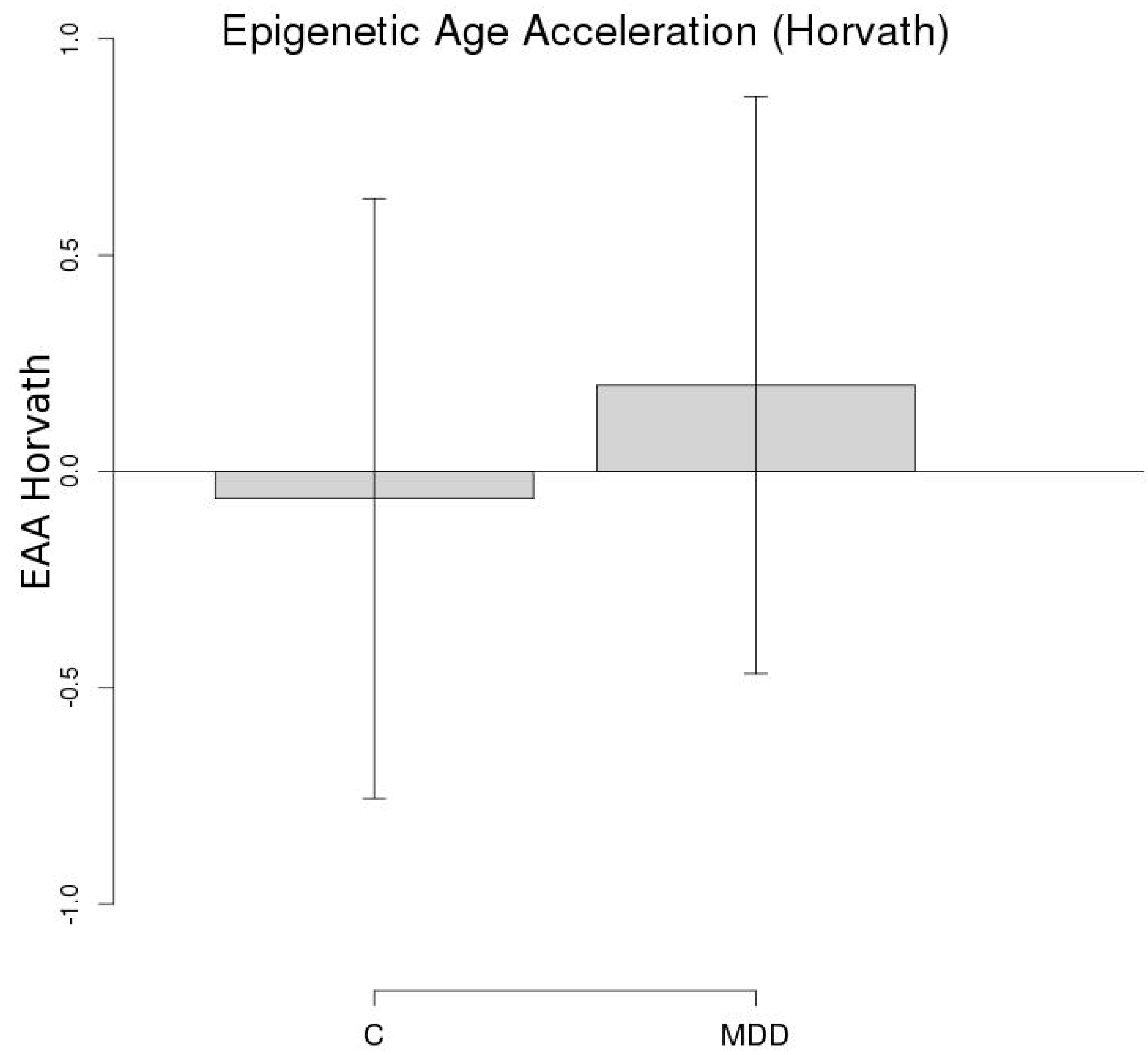


Group CTRL MDD 


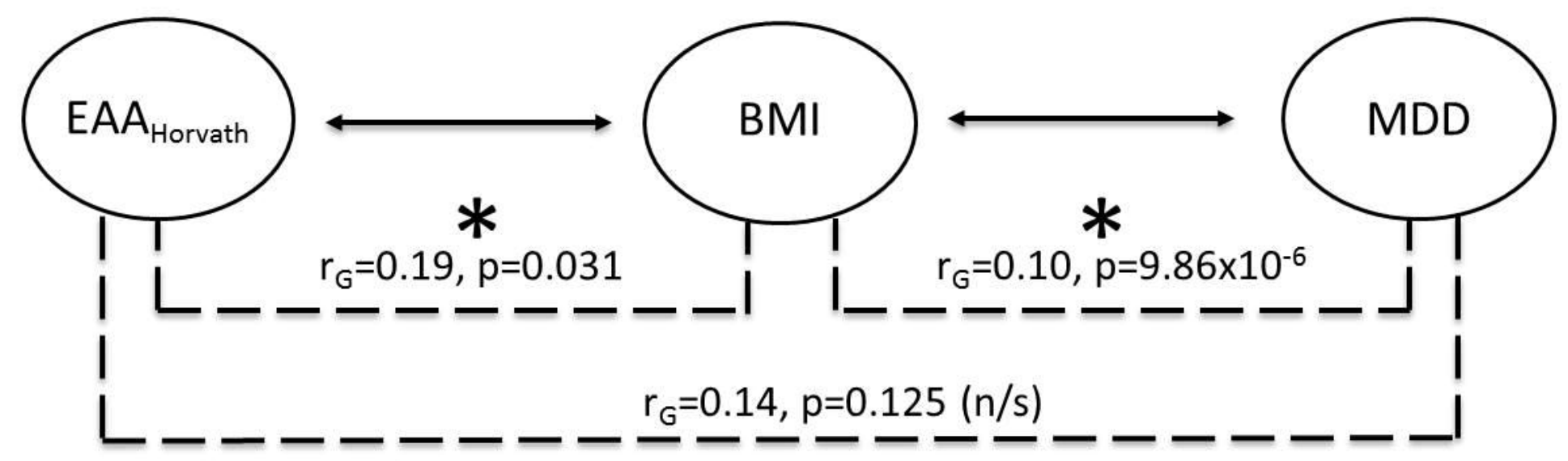

- - - - Genetic correlation

- Mediation (Sobel test) : $\beta=0.0028, p=0.0248$ 